\title{
PASADOS CONTEMPORÁNEOS
}

Acercamientos interdisciplinarios a los derechos humanos y las memorias en Perú y América Latina

Lucero de Vivanco y María Teresa Johansson (eds.) 